\title{
DAMPAK SIARAN TELEVISI TERHADAP KEUTUHAN RUMAH TANGGA PASANGAN USIA MUDA DI ACEH
}

\author{
Hamdani. AG \\ Institut Agama Islam Negeri (IAIN) Lhokseumawe \\ E-mail: hamdaniag.70@gmail.com
}

\begin{abstract}
Abstrak
Penelitian ini berjudul "Dampak Siaran Televisi terhadap Keutuhan Rumah Tangga Pasangan Usia Muda di Aceh, mengangkat tiga rumusan masalah; Bagaimana Dampak Siaran Televisi terhadap Keutuhan Rumah Tangga Pasangan Usia Muda di Aceh dan Bagaimana Wanita Aceh Pedalaman Memirsa Siaran Televisi, Bagaimana Siaran Televisi Berpengaruh terhadap Keutuhan Rumah Tangga Mereka, dengan tujuan penelitian untuk menjawab ketiga rumusan masalah di atas. Penelitian ini didesaign sebagai penelitian kualitatif dengan informan sebagai narasumber yang dipilih dari berbagai kalangan, termasuk para isteri - pelaku kekerasan itu. Menggunakan teori kultivasi (cultivation theory) dan teori penjajahan budaya (cultural imperialism theory) sebagai panduan penelitian dan pisau bedah masalah yang ada. Adapun hasil penelitian menunjukkan bahwa; 1) Dampak konten siaran televisi terhadap keutuhan rumah tangga pasangan usia muda sangat signifikan terutama konten siaran sinetron dan film plus siaran infotaimen yang kurang mendidik sehingga sulit dicerna oleh pemirsa kalangan awam; baik secara kognitif; afektif maupun behavioral, ketiga pengaruh ini terjadi karena meniru apa yang mereka lihat di layar kaca, setiap hari. Karena keawamannya mereka mengira apa yang ditonton di sinetron dan film sebagai peristiwa nyata (bukan ilusi atau fiksi) yang patut ditiru. Perubahan pengetahuan, sikap dan prilaku ini mendorong perempuan (para isteri) di Aceh untuk mencoba mempraktekkannya termasuk strategi berselingkuh dengan lelaki lain, yang dinilai berpenampilan lebih baik dibandingkan suaminya kere, kampungan dan petani tidak seperti lelaki yang dilihatnya di sinetron India. Hal inilah yang mendorong mereka berselingkuh dan menyingkirkan (membunuh) suaminya yang sah. Kekerasan ini diawali oleh konflik rumah tangga yang berlanjut ke dua pilihan, pertama mengajukan gugatan cerai ke Pengadilan dan kedua menghabisi suaminya sendiri, apalagi perempuan berpendidikan rendah dan minim ajaran agama, didorong oleh kenikmatan berzina dengan lelaki lain. 2) Dorongan ini terjadi karena mereka memirsa siaran televisi secara fanatis - mengikuti cerita sinetron bersambung tanpa putus, akibatnya mereka memirsa secara psikologis dan penuh perasaan terhadap aktor/artis tertentu. 3). Siaran televisi swasta nasional berpengaruh kuat bagi wanita Aceh pedalaman terutama siaran asing (impor) yang berbeda tradisi dan latar belakang sosial dengan mereka, padahal siaran ini sangat tidak mendidik bahkan bertolak belakang dengan nilai-nilai budaya dan agama masyarakat lokal. Padahal, siaran tersebut sangat tidak layak tayang baik secara agama, moral dan budaya selain juga mengandung konten kekerasan, sehingga, apa yang dilihat di sinetron dan film, cenderung ditiru dan dijadikan studi kasus oleh pemirsa perempuan di Aceh untuk dipraktekkannya. Sementara siaran infotaiment menyisakan tradisi kawin-cerai di kalangan para selebritis yang juga dijadikan
\end{abstract}


model oleh para pemirsa wanita Aceh, tidak peduli akibat psikologis bagi anakanak mereka yang terpisah kedua orang tuanya. Mereka tidak peduli lagi tujuan berumah tangga untuk mewujudkan keluarga samawa (Sakinah, Mawaddah Warahmah) yang diidolakan banyak pasangan suami- isteri.

Kata Kunci: Media Televisi, Kekerasan, Perselingkuhan.

\begin{abstract}
This studi, entitle of "The Effect of Television Broadcasting on Household Integrity of Young Couples in Aceh, (Analysis of Three Cases of Violence against Husbands in North Aceh), raises two problem formulations; How is the influence of television broadcasting on household integrity of young couples in Aceh and how the content of television broadcasts affects the violence of wives against husbands and the research objectives are to answer the two problem formulations above. This research is designed as a qualitative research with informants as sources who are selected from various groups including the wife of the perpetrator of the violence themselves. Using the cultivation theory of cultivation theory and the theory of cultural colonization (cultural imperialism theory) as a research guide and scalpel of the existing problems. The research results show that; 1) the influence of the mass media on the integrity of the households of young couples in Aceh through a) cognitive (changes in knowledge) both negative and positive, b) affective (changes in attitudes) and c) behavioral (changes in behavior), these three influences occur due to imitation what they see on the screen, in the form of news, soap operas, films, quizzes and infotainments (coverage of celebrity life) and the violence itself. This change in knowledge, attitudes and behavior encourages women (wives) in Aceh to try to practice it, including the strategy of having an affair with other men, even the strategy of getting rid of (killing) their own legitimate husband. This violence was preceded by domestic conflict (husband-wife squabbling) which continued into two options, first filing for divorce and secondly killing her own husband, especially women with low education and minimal religious teachings (Islam), driven by the pleasure of adultery and male seduction. other. 2) Television broadcast content that affects violence against husbands, especially entertainment broadcast content such as soap operas, films and infotainments that are dry with education, morality and religion. Thus, what is seen in soap operas, films, infotainments and violence itself tends to be imitated and used as a case study by female viewers in Aceh for their practice.
\end{abstract}

Keywords: Television Broadcasts, Violence, Adultery.

\title{
PENDAHULUAN
}

Kemajuan teknologi komunikasi sejak awal abad 20 telah melahirkan banyak perubahan dalam kehidupan sosial masyarakat, mulai gaya hidup, pakaian, cara bicara, hubungan keluarga, hubungan sosial bahkan jam tidur hampir semuanya diatur media massa. Efek komunikasi massa termasuk televisi di 
dalamnya, dapat dikaji melalui dua sudut pandang, yaitu; Pertama, efek kehadiran media massa di tengah-tengah kehidupan manusia telah memberikan pengaruh terhadap pola kehidupan mereka seperti aspek ekonomi, sosial, budaya, gaya hidup, penjadwalan kegiatan sehari-hari dan sebagainya. Kedua, pesan-pesan yang disampaikan melalui media massa baik langsung maupun tidak langsung, baik terencana maupun tidak telah mempengaruhi khalayak yang meliputi efek pengetahuan dan pemahamannya (efek kognitif), efek pembentukan dan perubahan sikap (efek afektif), dan efek pembentukan dan perubahan prilaku (efek behavioral) ${ }^{1}$

Sementara Steven H. Chaffee, menyebut lima efek media massa, yaitu 1) efek ekonomi, 2) efek sosial, 3) efek pada penjadwalan kegiatan, 4) efek pada penyaluran/penghilangan perasaan tertentu, dan 5) efek pada perasaan orang terhadap media. Namun, pendapat Steven H. Chaffee ini bertentangan dengan fungsi komunikasi awal yang berkaitan dengan fungsi informasi, fungsi mendidik, fungsi menghibur, dan fungsi mempengaruhi ${ }^{2}$. Pengaruh televisi bukan hanya terjadi secara positif seperti informasi cepat dari berbagai belahan dunia, pengetahuan praktis tentang politik, kesehatan, ekonomi dan budaya, pola pikir, gaya hidup, dan gaya bicara, melainkan juga pengaruh negatif misalnya perubahan prilaku - yang disadari atau tidak, perubahan budaya (kebiasaan), gaya hidup (live style), pornografi, kekerasan, dan konflik melalui tayangan film, sinetron, infotainment, musik, berita dan sebagainya ${ }^{3}$.

Sementara Mc Quail menyebutkan ada enam perspektif pengaruh media bagi pemirsa, yaitu Pertama, media bisa dilihat sebagai jendela dunia yang menginformasikan kita semua hal; Kedua, media bisa disebut cermin peristiwa yang menyajikan berbagai jenis tayangan; Ketiga, media sebagai filter yang menyeleksi berbagai tayangan baik yang layak tayang maupun tidak; Keempat, media sering juga disebut penunjuk jalan, mengarahkan ketidak-pastian yang beragam; Kelima, media sebagai forum untuk mempresentasikanberbagai informasi dan ide-ide kepada khalayak; dan Keenam, media massa juga sebagai arus

\footnotetext{
${ }^{1}$ Jalaluddin Rahmat, Psikologi Komunikasi, (Bandung: Remaja Rosdakarya, 2008), 217.

${ }^{2}$ Marhaeni Fajar, Ilmu Komunikasi; Teori dan Praktek, (Jogyakarta: Graha Ilmu, 2009), 3.

${ }^{3}$ Indra Iswadi, dalam Media Dengarkan Aku, (Jogyakarta: Kaki Koe dan Jur. Komunikasi Univ. Muhammadiyah, Malang, 2010), 62.
} 
informasi dan partner komunikasi yang interaktif ${ }^{4}$. Dengan semua itu media ingin menunjukkan perannya dalam kehidupan sosial, bukan sekedar media pelepas ketegangan atau hiburan semata tetapi isi dan informasi yang signifikan dalam proses sosial. Isi media massa merupakan khalayak otak dari informasi-informasi, sehingga apa yang ada pada media mempunyai peran yang sangat penting bagi kehidupan masyarakat. Karena itu, pemirsa harus berkemampuan untuk memilahmilah dan bisa memahami apa maksud media, supaya tidak salah mengartikan suatu tayangan media tertentu karena berpengaruh kuat bagi realitas masyarakat ${ }^{5}$.

Bagi kalangan masyarakat awam berpendidikan rendah di kawasan pedalaman, seperti di Provinsi Aceh, media massa televisi melebihi sekedar sarana hiburan dan informasi. Mereka mengira semua tayangan di televisi adalah realitas peristiwa sebenarnya (fakta) yang terjadi di belahan bumi lain, seperti halnya informasi dalam berita peristiwa, sehingga mereka memirsanya dengan penuh perasaan. Termasuk tayangan film dan sinetron (hasil karya fiksi para seniman) yang diolah sedemikian rupa untuk menarik perhatian pemirsa. Padahal, budaya media (media culture), menurut Douglas Kellner (1996) dalam bukunya "Media culture: Cultural Studies, Identity and Politics between the Modern and the Post Modern", menunjukkan pada suatu keadaan dimana tampilan audio dan visual atau tontonan-tontonan, telah membantu merangkai kehidupan sehari-hari, mendominasi proyek-proyek hiburan, membentuk opini politik dan prilaku sosial, bahkan memberi supplay materi untuk membentuk identitas seseorang. Media cetak, radio dan televisi, film, internet dan bentuk akhir teknologi media lainnya telah menyediakan defenisi-defenisi untuk menjadi laki-laki dan perempuan, membedakan status-status seseorang berdasarkan kelas, ras maupun seks.

Tayangan sinetron dan film India yang ditayangkan sejumlah stasiun televisi swasta nasional memberi pengaruh signifikan bagi kalangan ibu-ibu muda di Aceh, mereka sangat gandrung terhadap para aktor India yang rata-rata simpatik, kaya, ganteng dan berpostur tinggi besar, seperti Shahrukh Khan, dan lain-lain. Pengaruh ini justru melahirkan rasa kurang simpati terhadap penampilan para suami

\footnotetext{
${ }^{4}$ Mc Quail, Teori Komunikasi Massa, (Jakarta: Penerbit Erlangga, 1987), 66.

5 Irfan Dwi Susanto, dalam Media Dengarkan Aku, (Jogyakarta: Kaki Koe dan Jur. Komunikasi Univ. Muhammadiyah, Malang, 2010), 62.
} 
mereka yang laki-laki lokal, secara umum kampungan, berpostur kerdil, kere, kulit berwarna, serta cendrung kurang simpati karena hanya berprofesi sebagai petani, nelayan atau pekerja kasar lainnya. Di sisi lain, ada tayangan infotainment yang menyajikan informasi kawin-cerai para kaum selebritis yang tidak jarang tanpa masalah serius dalam rumah tangga - hanya rasa jenuh atau bosan terhadap pasangannya. Tayangan di stasiun televisi nasional, ini juga mendorong para ibuibu muda di Aceh untuk berpisah dengan para suami mereka, sehingga ikut-ikutan menggugat cerai para suami mereka ke Pengadilan Agama, tanpa peduli dampak negatif secara psikologis bagi anak-anak mereka dikemudian hari. Dampak dari kedua tayangan televisi ini bagi kalangan ibu-ibu muda di Aceh, terlihat dari kian menjamurnya data perkara gugatan cerai isteri terhadap para suami di berbagai Pengadilan Agama di Aceh. Sebagian besar kasusnya adalah masalah ekonomi, poligami dan perselingkuhan dan tuntas dengan vonis cerai. Ironisnya, sebagian kasus permusuhan terhadap suami, justru berakhir kekerasan terhadap para sang ayah, mereka bahkan dihabisi oleh para isteri berkonspirasi dengan selingkuhan mereka, seperti yang terjadi terhadap tiga korban di Kabupaten Aceh Utara selama 2016-2019 silam. Berdasarkan realitas di atas penulis tertarik membawa fenomena ini ke dalam penelitian ilmiah di bawah judul "Dampak Siaran Televisi terhadap Ketutuhan Rumah Tangga Pasangan Usia Muda di Aceh”

Penelitian ini mengangkat tiga masalah utama yaitu; bagaimana dampak siaran televisi terhadap keutuhan rumah tangga pasangan usia Muda di Aceh; dan bagaimana wanita Aceh pedalaman memirsa siaran televisi, dan bagaimana siaran televisi berpengaruh terhadap keutuhan rumah tangga, dengan tujuan penelitian, untuk menganalisis dampak siaran terhadap keutuhan rumah tangga pasangan usia muda, dan untuk menjawab cara wanita Aceh pedalaman memirsa siaran televisi dan menemukan siaran seperti apa yang berpengaruh terhadap keutuhan rumah tangga.

\section{KAJIAN DAN PEMBAHASAN}

\section{A. Kajian Operasional}

Untuk menyamakan persepsi atas istilah tertentu yang ada dalam kalimat judul di atas, berikut ini diberikan beberapa pengertian operasionalnya, yaitu: 


\section{Media Massa Siaran.}

Media Massa adalah media untuk operasional komunikasi massa. Yaitu bentuk media penyampaian pesan kepada khalayak luas, anonim dan hiterogen secara serempak, tanpa sekat waktu. Komunikasi massa sendiri merupakan salah satu disiplin kajian ilmu sosial selain psikologi, sosiologi, ilmu politik dan ekonomi. Komunikasi massa adalah studi ilmiah tentang media massa diantaranya surat kabar, radio, televisi, tabloid, majalah, internet, buku dan kaset $\mathrm{CD}$, beserta pesan yang dihasilkan, pembaca/pendengar/penonton yang coba diraihnya dan efeknya terhadap mereka. Pembahasan komunikasi yang kian pesat dan kompleks beserta penelitian yang terus-menerus dilakukan menjadi bukti bahwa ilmu komunikasi massa menjadi bagian penting dalam proses kajian keilmuan.

Sementara Michael W. Gamble dan Teri Kwal Gamble (1986) seperti dikutip Nurudin, mendefinisikan komunikasi massa, sebagai berikut: 1). Komunikator dalam komunikasi massa mengandalkan peralatan modern untuk menyebarkan atau memancarkan pesan secara cepat kepada khalayak yang luas dan tersebar; 2) komunikator dalam komunikasi massa dalam menyebarkan pesanpesan bermaksud mencoba berbagai pengertian dengan jutaan orang yang tidak saling kenal satu sama lain; 3) pesan adalah milik publik, artinya bahwa pesan ini bisa didapat dan diterima oleh banyak orang; 4) sebagai sumber, komunikator massa biasanya organisasi formal seperti jaringan, ikatan atau perkumpulan; 5) komunikasi massa dikontrol oleh gatekeeper (penjaga gawang); 6) Umpan balik dalam komunikasi massa sifatnya tertunda.

Kelebihan media massa dibandingkan dengan jenis komunikasi lainnya adalah ia bisa mengatasi hambatan ruang dan waktu. Bahkan, media massa mampu menyebarkan pesan hampir seketika pada waktu yang tak terbatas. Herbert Blumer membatasi komunikasi massa dengan ciri-ciri sebagai berikut: 1) heterogenitas susunan anggotanya yang berasal dari berbagai kelompok lapisan masyarakat; 2) berisi individu yang tidak saling mengenal dan terpisah satu sama lain; 3) ridak mempunyai pemimpin atau organisasi formal.

Salah satu kemajuan masyarakat, diakui atau tidak, disebabkan oleh peran media massa. Namun sebaliknya, kekacauan, kemerosotan moral dan tindak kekerasan yang timbul di masyarakat juga tidak bisa dilepaskan dari peran media 
massa. Dengan demikian, media massa merupakan faktor penentu kehidupan manusia. Untuk sekedar mengilustrasikan fenomena tersebut, jawablah pertanyaan berikut. Berapa persen pikiran, ucapan, dan prilaku kita dipengaruhi oleh media massa - tentu saja sangat fantastis. Media massa yang menjadi fokus kita dalam proposal ini adalah media televisi dan handphone digital.

\section{Pasangan Usia Muda}

Pasangan usia muda adalah salah satu jenjang (tahapan) dalam kehidupan rumah tangga anak manusia. Tidak ada batas umur pasti bagi kalangan pasangan usia muda, yang jelas mereka sudah menikah dan hidup terpisah dengan orang tua mereka. Jika mereka menikah pada usia 25 tahun (bagi laki-laki) dan 20 tahun (bagi perempuan), maka hingga usia pernikahan 10 - 15 tahun (beranak dua atau tiga) masih dianggap pasangan usia muda. Salah satu karakteristik pasangan ini masih memiliki hasrat seks (libido) tinggi terhadap pasangannya. Faktor libido inilah yang mengundang banyak cobaan, tantangan dan godaan bahkan perselingkuhan dalam kehidupan rumah tangga pasangan ini. Hal inilah yang dapat dengan sangat mudah dipengaruhi pihak luar rumah tangga mereka, baik yang datang dari pihak ketiga, lingkungan maupun media massa - terutama ada kecendrungan membandingkan dengan pasangan mereka sendiri dengan para tokoh dalam siaran media televisi.

\section{Kedudukan Isteri dalam Islam}

Isteri dalam ajaran Islam diposisikan sebagai pasangan hidup yang mendampingi suami, menjadi hiburan, pelipur lara dan penenang hati suaminya. Namun, hukum keluarga Islam secara tegas disebutkan bahwa laki-laki (suami) adalah pemimpin bagi kaum wanita (isteri), dijelaskan dalam Alqur'an.

" Kaum lelaki itu adalah pemimpin bagi kaum wanita, oleh karena Allah Swt telah melebihkan sebagian mereka (laki-laki) atas sebagian yang lain (wanita), karena mereka (laki-laki) telah menafkahkan sebagian dari harta mereka” (QS. An-Nisa (4): 34).

Karena itu, sudah merupakan kewajiban bagi kaum lelaki untuk menjadi pemimpin bagi kaum wanita, dengan memberi perlindungan dan pemeliharaan terhadap mereka. Kelebihan kaum pria atas wanita adalah mengakar pada asal kejadiannya. Allah memberikan anugerah kepada pria berupa kemampuan dan kekuatan, yang tidak dimiliki oleh wanita. Karena itu, perbedaan kewajiban dan 
hukum adalah diakibatkan oleh adanya perbedaan "fitrah" kejadian dan perangkatperangkat yang dimilikinya.

Islam mengatur persoalan hukum suami-isteri secara jelas, bahkan sampai persoalan nusyuz (perlawanan isteri atas suami) dan pemberontakan isteri dalam soal seks pun diatur.

"Wanita-wanita yang kamu khawatiri nusyuznya, maka nasehatilah mereka dan pisahkanlah diri dari tempat tidur mereka dan pukullah mereka. Kemudian jika mereka mentaatimu, maka janganlah kamu mencari-cari jalan untuk menyusahkannya”.

Tim Kementrian Agama menyebutkan bahwa nusyuz artinya meninggalkan kewajiban bersuami-istri seperti meninggalkan rumah tanpa izin suaminya. Nah, jika nusyuz saja menjadi perbuatan hukum melawan suami, yang diasosiakikan sebagai durhaka pada suami, bagaimana pula dengan perbuatan membangkang, selingkuh (mengkhianati) atau bahkan berkonspirasi melakukan kekerasan (membunuh suami), sungguh suatu perbuatan sangat tercela dan tidak bermoral.

\section{B. Riset Terdahulu yang Relevan}

Penelitian terdahulu terkait pengaruh media massa dapat dijelaskan sebagai berikut:

1. Riset Dr. Hamdani. AG, MA tahun 2018 berjudul Pengaruh kesenjangan informasi terhadap Radikalisme di kalangan masyarakat pedalaman Kab. Aceh Utara. Penelitian ini mengungkapkan besar sekali pengaruh kesenjangan informasi di kalangan masyarakat pedalaman, terutama karena masyarakat pedalaman kurang memberi perhatian pada siaran informasi TV, mereka lebih memperhatikan siaran hiburan seperti sinetron, olah raga dan musik. ${ }^{6}$

2. Riset Asnil Aidah Ritonga, 2007, "Dampak Penayangan Misteri dalam Program TV Terhadap Penghayatan Agama dan Prilaku Anak-anak SD di Kecamatan Batang Kuis -Sumut”. Penelitian tahun 2007, ini menyimpulkan dampak tayangan misteri di layar TV memberi

\footnotetext{
${ }^{6}$ Riset, Hamdani. AG, 2019, tidak dipublikasi
} 
pengaruh kuat terhadap penghayatan agama dan prilaku anak -anak SD di Kecamatan pesisir tersebut. ${ }^{7}$

3. Riset Said Muhammad Tahun 2011, "Pengaruh Tayangan Kartun "Naruto" di TV Terhadap Perkembangan Psikologis dan Prilaku Anakanak Madrasah di Kecamatan Muara Dua, Kota Lhokseumawe”. Penelitian tahun 2012, ini menyimpulkan kuatnya pengaruh psikologis dan prilaku anak-anak yang menonton tayangan kartun Naruto di layar $\mathrm{TV}$, terutama prilaku kekerasan terhadap teman-temannya, saat berada di sekolah ${ }^{8}$.

Ketiga riset terdahulu ini yang sama-sama menjadikan siaran televisi sebagai objek penelitian untuk melihat bagaimana dampaknya bagi masyarakat, individu dan budaya yang sangat rawan apalagi siaran impor dari negara-negara Barat yang berbeda budaya, tradisi dan ideologi dengan masyarakat lokal. Sedangkan penelitian ini mengkhususkan diri pada dampak terhadap keutuhan rumah tangga pasangan usia muda di kawasan pedalaman, Aceh, terutama yang diawali oleh perselingkuhan isteri dengan lelaki lain, yang berlanjut ke pembunuhan suami secara sadis.

\section{Kajian Pustaka.}

\section{Paparan Kasus.}

Kasus Pertama menimpa Tarmizi (34) penduduk Desa Pulo Rungkom, Kecamatan Dewantara yang dihabisi Chairul Saputra alias Mahonk (28), pada 24 Desember 2016 dengan cara memukul dan menggorok leher korban. Pelaku pembunuhan pedagang kulit sapi ini Mahonk adalah penduduk Desa Balimbingan, Kecamatan Tanah Jawa, Kabupaten Simalungun, Sumut tidak lain adalah selingkuhan isterinya Ita Sariyanti (29) yang dikenalnya melalui media sosial dan sudah berulang kali tidur bersama ketika korban tidak di rumah.

Pembunuhan ini dilakukan secara sadis di rumah korban dan didepan anak dan isterinya, sekira pukul 14.30 wib, saat korban pulang ke rumahnya menemukan ada lelaki lain bersama isterinya yang memang menginap di rumah korban. Selesai menghabisi korban pelaku kabur dengan sepeda motor korban, namun atas laporan

\footnotetext{
${ }^{7}$ Riset Asnil Ritonga, Jurnal Analitica Islamica, UIN Sumut, Vol. 13, No. 1 Mei 2011

${ }^{8}$ Riset Said Muhammad, Skripsi FUAD IAIN Lhokseumawe, 2011.
} 
tetangga korban, polisi berhasil meringkusnya di Simpang Pangkalan Susu, Sumatera Utara dengan mengumpan isteri korban. Pelaku utama pembunuhan sadis ini telah divonis PN Lhoksukon, dengan hukuman penjara masing - masing Ita dan Mahonk seumur hidup; Kedua menimpa Jajuli (34) penjual es campur, dibunuh Musliadi alias Adi (34) selingkuhan isteri korban Jamaliah (36) saat korban tertidur nyenyak di kamar rumahnya di Kecamatan Matang Kuli, pada Februari 2019. Korban dibunuh secara sadis dengan menggorok lehernya bersama-sama dengan isteri korban yang memiliki hubungan gelap dengan pelaku, serta merekayasa seakan-akan korban dibunuh perampok, kedua pelaku sudah divonis PN Lhoksukon masing-masing Adi seumur hidup dan Jamaliah 20 tahun penjara; dan Ketiga terjadi di Desa Teupin Reusep, Kecamatan Sawang, pembunuhan Muhammad Amin alias Nek Min (73) dihabisi oleh Safrizal (35) selingkuhan isteri korban Marliah (35), saat dicegat dalam perjalanan pulang dari kebun pinang korban di Desa Teupin Reusep, Kecamatan Sawang Aceh Utara, pada 26 Juli 2018. Kedua pelaku utama pembunuhan ini dijatuhi hukuman seumur hidup di PN Lhoksukon.

\section{Kekerasan didalangi Perempuan}

Ketiga kasus pembunuhan terhadap para suami ini diotaki oleh isteri korban, karena dilatar-belakangi perselingkuhannya bahkan telah berulang kali melakukan perzinaan dengan lelaki lain. Perselingkuhan dan perzinaan inilah yang mendorong para pelaku nekad menghabisi korban, sebab dianggap bisa menjadi penghalang hubungan gelap mereka. Ketiga kasus ini nyaris bermotif tidak berbeda, yaitu didahului oleh perselingkuhan isteri dengan lelaki gelap, lalu muncul konflik (percek-cokan) rumah tangga dan pertengkaran hebat, hingga akhirnya muncul niat untuk menikah setelah menghabisi korban secara bersama-sama.

Ironisnya, kasus pembunuhan terhadap para suami ini dilakukan perempuan Aceh yang konon bersikap sangat santun dalam beragama (Islam) serta panut terhadap suami. Tidak sedikitpun terbayangkan dalam benak banyak orang kalau kekerasan mampu dan tega dilakukan oleh seorang perempuan berkarakter muslim seperti wanita Aceh. Sebab, selain tidak memiliki latar belakang sejarah terlibat dalam kasus-kasus kekerasan besar, juga mereka sedikit banyaknya memahami ajaran agama dengan baik. Mereka sangat mahfum dengan resiko dosa besar melawan suami, jangankan membunuh suami membantah perkataannya saja sudah 
berdosa (durhaka) yang konsekuensinya adalah neraka jahannam. Kalau tiba-tiba ada perempuan Aceh yang menjadi otak pembunuhan terhadap para suami mereka sekaligus ayah dari anak-anak mereka, ini pasti ada hal lain di luar mereka yang harus dicurigai sebagai faktor penyebab perubahan perilaku, sikap dan tradisinya.

Ketika itulah, media massa televisi plus media sosial yang semakin akrab dengan kehidupan masyarakat Aceh khususnya kalangan perempuan yang berada di kawasan pedalaman, menjadi sasaran utama penyebaran perubahan tersebut, baik secara kognitif, afektif maupun behavioral.

\section{Pendekatan Teoretis}

\section{Teori Kultivasi (teori penanaman)}

Teori Kultivasi dikemukakan oleh George Gerbner, imigran AS kelahiran Hongaria 1919, terakhir menjadi dosen di Universitas Pennsylvania 1964 - 1989, hingga meraih profesor komunikasi tahun 1997 di Universitas Temple ${ }^{9}$ Tulisan pertama yang memperkenalkan teori ini adalah Living with Television: The Violenceprofile, Journal of Commonication, pada tahun 1962, yang mempelajari pengaruh menonton televisi di kalangan pemirsa. Gerbner ingin mengetahui dunia nyata seperti apa yang dibayangkan dan dipersepsikan oleh penonton televisi. Penelitian ini lebih menfokuskan diri pada "dampak". ${ }^{10}$

Analisis awal teori kultivasi cenderung pada defenisi violence (kekerasan) yang diasumsikan berasal dari pengaruh tayangan televisi. Gerbner merumuskan, media massa (televisi) membentuk atau menanam dalam diri masyarakat bahwa yang digambarkan televisi melalui tayangannya adalah gambaran dunia yang sesungguhnya. Ia berkesimpulan bahwa media televisi berpengaruh yang kuat terhadap masyarakat.

Karena mendapat kritik tajam dari rekan-rekannya tentang Indeks Kekerasan dan pembuktian yang kurang meyakinkan dari hubungan kausal antara level fluktuasi aniaya dari televisi dan prilaku agresif para penonton, akhirnya Gerbnerpun tahun 1973 menyempurnakan penelitiannya melalui proyek Indikator Kultural, yang kemudian menghasilkan lima asumsi teorinya, yaitu: Pertama, Pustaka, 2012.

9 Kamaluddin, Bagian Buku dalam Syukur Kholil, Teori Media massa, Ciptamedia

${ }^{10}$ Nuruddin. Pengantar Komunikasi Massa. Jakarta: Raja Grafindo Perkasa, 2007. 
televisi secara esensial dan fundamental berbeda dari media massa lainnya. Media massa televisi dimiliki oleh 98 persen rumah tangga di AS dan juga Indonesia. Televisi tidak memerlukan melek huruf, sebagaimana surat kabar, majalah, dan buku. Siaran televisi memadukan suara dan gambar (audio -visual), dan gratis dan tidak memerlukan mobilitas seperti film dan bioskop; Kedua, televisi merupakan alat kultural utama dari masyarakat dan pencipta utama dari pola-pola kultural sintetis (hiburan dan informasi) untuk publik massa yang heterogen dalam sejarah.

Ketiga, mengalir secara logika dari realita yang ada bahwa kebanyakan stasiun dan jaringan televisi didukung secara komersial (dan oleh karena itu berakar dalam status quo) dan menargetkan lebih kurang audiens yang sama, mereka tergantung pada bentuk-bentuk program dan cerita yang relatif umum, bersiklus dan repetitif; Keempat, gagasan bahwa fungsi kultural utama televisi adalah untuk menstabilkan pola-pola sosial, untuk menanamkan penolakan terhadap perubahan, ini adalah media sosialisasi dan enkulturasi; Kelima, kontribusi dapat dilihat, dapat diukur, independen dari televisi terhadap kebudayaan adalah relatif kecil yang menyebabkan kontroversi tambahan. ${ }^{11}$

Awalnya teori kultivasi lebih menfokuskan kajian pada studi televisi dan audience, khususnya pada tema-tema kekerasan di televisi, tetapi dalam perkembangannya teori ini bisa digunakan untuk kajian diluar tema kekerasan terutama daya tarik audience terhadap opera sabun (heavy soap opera) atau pecandu sinetron, musik dan film. Pemirsa pecandu opera, sinetron dan filmtersebut lebih cenderung melakukan affair (perselingkuhan), bercerai, dan mengugurkan kandungan, menuntut persamaan gender dibandingkan dengan mereka yang bukan pecandu. ${ }^{12}$ Gerbner akhirnya mengidentifikasi tiga asumsi dasar teori kultivasi, yaitu:

a) Televisi blurs (mengaburkan) perbedaan tradisi dari pandangan orangorang tentang dunia mereka.

b) Televisi blends (memadukan) realita mereka ke dalam mainstreen kultural televisi

\footnotetext{
${ }^{11}$ Ibid, 201.

${ }^{12}$ Ibid, 166.
} 
c) Televisi bends (membelokkan) mainstreen tersebut pada kepentingan institusional dari televisi dan sponsor-sponsornya.

\section{Cultural Imperialism Theory (teori penjajahan budaya)}

Teori ini pertama kali dikemukakan oleh Herb Schiller pada tahun 1973. Tulisan pertama Schiller yang dijadikan dasar munculnya teori ini adalah Communication and Cultural Dommination. Teori imperialisme budaya ini menyatakan bahwa negara Barat mendominasi media di seluruh dunia terutama di negara-negara dunia ketiga. Alasannya, media massa Barat mempunyai efek yang kuat untuk mempengaruhi media dunia ketiga, baik teknologi maupun konten siarannya. Dalam perspektif teori, konten siaran media Barat terjadi proses peniruan oleh pemirsa media di negara berkembang, saat itulah berlangsung penghancuran budaya asli di negara ketiga.

Kebudayaan Barat memperoduksi hampir semua konten siaran media massa di dunia ini seperti film, berita, komik, sinetron, kuiz, musik dan berbagai program siaran lainnya. Hal ini karena Barat didukung oleh beberapa faktor, diantaranya; Pertama, mereka mempunyai uang sebagai modal utama dalam memproduksi program siaran; dan Kedua, mereka mempunyai teknologi modern yang memungkinkan sebagai pendukung utama produksi siaran tersebut, sehingga menarik berbagai kalagan pemilik media massa dunia.

Kondisi ini mendorong para owner media televisi untuk membeli program siaran tersebut untuk medianya, apalagi harganya jauh lebih murah dibandingkan dengan memproduksi sendiri program siaran tersebut. Membeli konten siaran dari Barat selain lebih murah, mudah juga tidak ribet dalam proses produksi, tinggal mempekerjakan translater bahasa saja, langsung jadi.

Salah satu yang mendasari munculnya teori ini adalah bahwa pada dasarnya manusia tidak memiliki kebebasan untuk menentukan bagaimana mereka berpikir, apa yang dirasakan dan bagaimana mereka hidup. Umumnya mereka cenderung mereaksi apa saja yang dilihatnya di televisi. Akibatnya, individu-individu tersebut lebih senang meniru apa yang disajikan televisi, karena televisi menyajikan hal baru yang berbeda dengan yang biasa mereka lakukan. 


\section{E. Metodologi Penelitian}

\section{Jenis dan Pendekatan Penelitian.}

Penelitian ini menggunakan pendekatan deskriptif kualitatif yaitu suatu penelitian yang bertujuan mendiskripsikan atau menjelaskan sesuatu seperti apa adanya. Menurut Bogdan dan Taylor, metodologi kualitatif sebagai prosedur penelitian yang menghasilkan data deskriptif berupa kata-kata tertulis atau lisan dari informan, orang-orang dan perilaku yang dapat diamati. Pendekatan ini diarahkan pada latar dan individu tersebut secara holistik (utuh). Dalam hal ini tidak boleh mengisolasikan individu atau organisasi ke dalam variabel atau hipotesis, tetapi perlu memandangnya sebagai bagian dari sesuatu keutuhan. Sejalan dengan definisi tersebut, Kirk dan Miller mendefinisikan penelitian kualitatif adalah tradisi tertentu dalam ilmu pengetahuan sosial yang secara fundamental bergantung dari pengamatan pada manusia baik dalam kawasannya maupun dalam peristilahannya.

Dari kajian tentang definisi-definisi tersebut dapatlah dipahami bahwa penelitian kualitatif adalah penelitian yang bertujuan untuk memahami fenomena tentang apa yang dialami oleh subjek penelitian secara holistik dan dengan cara deskriptif dalam bentuk kata-kata dan bahasa pada suatu konteks khusus yang alamiah dan dengan memanfaatkan berbagai metode alamiah. Sedangkan jenis penelitiannya adalah menggunakan studi kasus. Studi kasus atau penelitian kasus adalah penelitian tentang subjek penelitian yang berkenaan dengan suatu fase spesifik atau khas dari keseluruhan personalitas. Subjek penelitian bisa saja individu, kelompok, lembaga maupun masyarakat. Peneliti ingin mempelajari secara intensif latar belakang serta interaksi lingkungan dari unit-unit sosial yang menjadi subjek. Tujuan studi kasus adalah untuk memberikan gambaran secara detail tentang latar belakang, sifat-sifat serta karakter-karakter yang khas dari kasus atau individu yang kemudian dari sifat-sifat khas diatas akan dijadikan suatu hal yang bersifat umum. ${ }^{13}$

Sedangkan jenis penelitian yang digunakan adalah jenis penelitian deskriptif yang memaparkan situasi atau peristiwa. Penelitian ini tidak mencari atau menjelaskan hubungan, tidak menguji hipotesis atau membuat prediksi. Metode

${ }^{13}$ Lexi J. Moeleong, Metodologi Penelitian Kualitatif, (Bandung: Remaja Rosdakarya, 2004), 212 
deskriptif mencari teori, bukan menguji teori; hypothesis-generating, bukan hypothesis-testing.

\section{Lokasi Penelitian}

Penelitian ini mengambil lokasi di Kecamatan Dewantara, Kecamatan Sawang dan Kecamatan Matang Kuli, Kabupaten Aceh Utara dan Lhokseumawe, yang selama 30 tahun terakhir dikenal sebagai Daerah Petro Dolar, menyusul adanya Kilang LNG Arun plus Industri Pupuk PT. Pupuk Iskandar Muda (PIM), PT. Aceh Asean Fertilizer (AAF), PT. Kertas Kraft Aceh (KKA) serta Perusahaan Eksporator LNG Mobil Oil, Inc. Yang menjadi sumber utama penyebab kesenjangan sosial sejak medio 1970-an silam.

Sumber data, menurut Lofland sebagaimana dikutip oleh Lexy J. Moleong, sumber data utama dalam penelitian kualitatif ialah kata-kata dan tindakan, selebihnya adalah data tambahan seperti dokumen dan lain-lain. Sumber data terdiri dari dua macam yaitu data primer dari narasumber yang diwawancarai dan data sekunder yang berasal dari catatan buku dan dokumen yang ditemukan.

Sementara informan kunci (key informant) sebagai narasumber utama penelitian untuk memperoleh data-data dipilih secara nonprobabilitas melalui teknik purposive (bertujuan), dengan kriteria-kriteria sbb: a). Mengetahui secara mendalam tentang kehidupan dan selera pasangan usia muda dan dinamikanya; b). Sering terlibat langsung dalam penyelesaian dan perdamaian konflik rumah tangga di kalangan pasangan usia muda; c). Memahami sedikit banyaknya tentang kewajiban, hak dan tanggung jawab suami/isteri dalam kehidupan rumah tangga. Mereka adalah 1. Perempuan (Ibu RT) pelaku Kekerasan terhadap suami ; 2. Akademisi bidang. pendidikan dan kehidupan sosial; 3. Pengadilan Syar'iyah Aceh Utara dan Lhokseumawe.

\section{Teknik Pengolahan dan Analisis Data}

Setelah data terkumpul dilakukan pemilahan secara selektif disesuaikan dengan permasalahan yang diangkat dalam penelitian. Setelah itu dilakukan pengolahan dengan proses editing yaitu dengan meneliti kembali data-data yang didapat, apakah data tersebut sudah cukup baik dan dapat segera dipersiapkan untuk proses berikutnya. Secara sistematis dan konsisten bahwa data yang diperoleh yang 
selanjutnya dituangkan dalam suatu rancangan konsep yang kemudian dijadikan dasar utama dalam memberikan analisis.

Analisis data menurut Patton yang dikutip oleh Moleong, adalah proses mengatur urutan data, mengorganisasikannya ke dalam suatu pola, kategori dan satuan uraian dasar. Sedangkan menurut Bogdan dan Taylor, analisa data adalah proses yang merinci usaha secara formal untuk menemukan tema dan merumuskan ide seperti yang disarankan data dan sebagai usaha memberikan bantuan pada tema ide itu. ${ }^{14}$

Dalam penelitian ini digunakan untuk menganalisa data yang sudah diperoleh adalah dengan cara deskriptif (non statistik), yaitu penelitian yang dilakukan dengan menggambarkan data yang diperoleh dengan kata-kata atau kalimat yang dipisahkan untuk kategori dalam memperoleh kesimpulan dengan maksud mengetahui keadaan sesuatu mengenai apa dan bagaimana, berapa banyak, dan sejauh mana. Pada umumnya penelitian deskriptif yang non hipotesis, dibedakan dalam dua jenis penelitian yaitu yang bersifat ekploratif dan yang bersifat developmental. ${ }^{15}$ Dalam hal ini peneliti menggunakan deskriptif yang bersifat ekploratif yaitu dengan menggambarkan keadaan atau status fenomena. Peneliti hanya ingin mengetahui hal-hal yang berhubungan dengan keadaan sesuatu. Dengan berusaha memecahkan persoalan-persoalan yang ada dalam rumusan masalah dan menganalisa data-data yang diperoleh dengan menggunakan pendekatan sosiologis.

\section{F. Paparan Data dan Hasil Penelitian.}

Dari data yang diperoleh menunjukkan bahwa ketiga kasus kekerasan terhadap para suami yang melibatkan para isteri ini, umumnya dilakukan para pelaku dalam kondisi sadar dan memiliki tujuan khusus dengan para selingkuhannya setelah menghabisi suami mereka. Hampir tidak berbeda ketiga pasangan selingkuhan ini sebelum memutuskan untuk menghabisi para suami malang ini sudah melakukan hubungan badan suami-isteri secara tanpa sah, umumnya dilakukan dibelakang suami mereka; adakalanya ketika suami tidak di

\footnotetext{
${ }^{14}$ Ibid, 122.

${ }^{15}$ Suharsimi Arikunto, Penelitian Kualitatif, (Jakarta: Prenada media Group, 2006), 27.
} 
rumah atau ketika suami dalam kondisi tidur. Hubungan gelap segitiga ini rata-rata sudah berlangsung lebih dari setahun dan sudah berulang kali melakukan hubungan gelap suami -isteri.

Media komunikasi antar pasangan ini selama ini berlangsung melalui media sosial (telapon, WA, Instagram atau SMS) - tidak siang, kadang juga berlangsung malam hari seperti yang dilakukan Mahonk alias Chairul Saputra (34) -laki-laki asal Kabupaten Simalungun, Sumut bersama selingkuhannya Ita Sariyanti (29) isteri korban Tarmizie (34) penduduk Desa Pulo Rungkom, Kecamatan Dewantara, Aceh Utara. Mahonk yang saat itu memilih kos di kawasan Krueng Geukueh, Aceh Utara - 20 km Barat Lhokseumawe, untuk memudahkan mencapai lokasi rumah Ita yang hanya berjarak sekitar 3 - 4 km dari lokasi kosnya. " Komunikasi kami selama ini lebih sering via WA atau telepon, umumnya malam hari ketika suami saya tidak di rumah", ujar Ita yang ditemui di LP wanita Lhoksukon, awal Mei lalu.

Ita mengakui sejak kenal dengan Mahonk setahun lalu, ia lebih mencintainya dibandingkan dengan suaminya yang memiliki sifat kikir dan ringan tangan kalau ada masalah. "Sejak sering terjadi cek-cok rumah tangga, sudah terlalu sering saya dipukulinya, disamping jarang sekali memberikan uang belanja ke saya, padahal kalau dia pergi kadang dua- tiga hari baru pulang”, katanya beralasan. "Sebagai lelaki Mahonk lebih baik, bertanggung jawab, sayang sama saya serta lebih gagah dibandingkan suami saya,itu sebabnya saya lebih lengket sama dia", tandas Ita lagi, meskipun ia tahu kalau berbuat jahat terhadap suami itu perbuatan dosa.

Hal yang sama juga diakui Jamaliah (34) penduduk Kecamatan Matang Kuli, Aceh Utara - salah seorang pelaku pembunuhan Jajuli (34) suaminya sendiri, bersama selingkuhannya Musliadi alias Adi (34). Suami saja tidak segagah Bang Adi, sudah itu kerjanya Cuma pedagang es campur yang kere, jangankan mau membeli honda sebagai kenderaan keluarga, untuk memenuhi kebutuhan hidup saja susah. Sudah itu, hampir tiap hari kami hidup cek-cok terus- dari persoalan ekonomi, beda pendapat hingga masalah keuangan rumah tangga. "Saya sudah coba bawa masalah kami ke keluarga, tetapi tetap tidak berubah, akhirnya saya tidak sabar", kata Jamaliah, sambil menambahkan kalau dia tahu betul tentang ketentuan agama Islam tentang kewajiban suami-isteri. 
Baik Ita maupun Jamaliah dan Marliah - Napi lainnya yang juga terlibat kasus hampir serupa, mengaku penggemar berat sinetron keluarga yang ditayangkan salah satu televisi swasta nasional - khususnya sinetron India, yang umumnya bertemakan drama rumah tangga. Ketika ibu muda ini senada mengakui memiliki pengetahuan dasar agama tentang kehidupan rumah tangga, apalagi terlibat dalam kekerasan terhadap suami mereka. "Keterlibatan dalam kekerasan terhadap suami bersama dengan selingkuhannya itu hanya sebuah kebetulan, karena kondisi dan dipaksakan teman konspirasi - itu saja", ujar Jamaliah, memelas sambil menunjukkan sikap rasa menyesal mendalam.

Tabel-1 Laporan -Perkara di Pengadilan Agama Syariyah Lhoksukon Periode $2018-2020$.

\begin{tabular}{|l|l|c|c|c|}
\hline No. & Jenis Perkara & P e r i o d e & & \\
\hline & & $\mathbf{2 0 1 8}$ & $\mathbf{2 0 1 9}$ & $\mathbf{2 0 2 0}$ \\
\hline 1. & Cerai Gugat & 429 & 523 & 599 \\
\hline 2. & Cerai Thalak & 156 & 151 & 162 \\
\hline 3. & Lain-lain & 515 & 751 & 500 \\
\hline
\end{tabular}

Tabel - 2 Laporan - Perkara di Pengadilan Agama Syariyah Lhokseumawe Periode $2018-2020$.

\begin{tabular}{|l|l|c|c|c|}
\hline No. & Jenis Perkara & P e r i o d e & & \\
\hline & & $\mathbf{2 0 1 8}$ & $\mathbf{2 0 1 9}$ & $\mathbf{2 0 2 0}$ \\
\hline 1. & Cerai Gugat & - & 231 & 241 \\
\hline 2. & Cerai Thalak & - & 76 & 94 \\
\hline 3. & Lain-lain & - & 212 & 202 \\
\hline
\end{tabular}

Dari tabel perkara yang masuk dan diputuskan Pengadilan Agama Syariyah Lhoksukon dan Lhokseumawe - dua wilayah yang semula masuk Kabupaten Aceh Utara itu terlihat tingginya angka kasus cerai gugat dan cerai talak di kalangan penduduk dua daerah itu. Di Pengadilan Agama Lhoksukon misalnya, angka perkara cerai gugat sebesar 429 tahun 2018 dari jumlah perkara yang diterima 1.100 kasus naik menjadi 523 tahun 2019 dari 1.426 perkara yang diterima dan naik lagi menjadi 599 tahun 2020 dari 1261 perkara yang masuk, menempati urutan pertama terbanyak setelah cerai talak yang hanya 156 tahun 2018 turun menjadi 151 tahun 
2019 dan kembali naik menjadi 162 tahun berikutnya, dan Isbath Nikah dan Dispensasi Kawin. Dan di PA Syariyah Lhokseumawe juga tidak berbeda yaitu perkara cerai gugat menempati urutan pertama dengan 231 kasus tahun 2019, naik menjadi 241 kasus tahun 2020. Sedangkan, urutan kedua adalah kasus cerai talak yang tahun 2019 m,enempati angka 76 naik menjadi 94 tahun 2020, serta kasus Isbath Nikah tahun 2019 tercatat 133 kasus dan menjadi 87 kasus tahun 2020.

Tren kenaikan secara signifikan kasus cerai gugat dan cerai talak di kedua PA tersebut menunjukkan tingginya angka konflik rumah tangga di kalangan penduduk Kabupaten Aceh Utara dan Lhokseumawe. Sementara, kasus yang berhasil dimediasi kecil sekali, karena suami-isteri saling ngotot, kata Ketua PA Syariyah Lhoksukon, Said Sofyan, SH, MH, yang juga mengaku prihatin dengan tren angka-angka tersebut.

Laporan kedua PA tersebut tandas Akademisi IAIN Lhokseumawe, Dr. H. Hafifuddin, M.Ag adalah fakta semakin kritisnya kondisi rumah tangga masyarakat kita akibat renggangnya hubungan antara suami dan isteri yang ditengarai pengaruh siaran televisi dan media sosial yang datang tanpa selang waktu, apalagi masyarakat kita kering ilmu agama dan moralitas di masyarakat.

Atas dasar status itulah, sedikit lelaki Aceh yang bisa menerima isteri bekerja di luar rumah dan mengabaikan tugas-tugas ibu rumah tangga seperti memasak, mencuci, mengurus anak dan sebagainya. Bagi banyak lelaki Aceh, okeoke saja adanya program gender atau emansipasi wanita - namun tetap saja tugas rumah tangga urusan isteri. Namun yang terjadi kemudian adalah kebanyakan isteri (wanita) di Aceh menjadi egois ketika berpenghasilan sendiri dengan bekerja di luar rumah plus pengaruh tontonan siaran televisi, sehingga mengabaikan tugasnya sebagai ibu rumah tangga, apalagi kalau sang suami miskin, kere dan kampungan dan tidak berpenghasilan, ditambah lagi dengan isteri kering pendidikan agama. Kondisi inilah yang justeru semakin melahirkan perselisihan suami-isteri - yang berbuntut konflik yang kian hari kian melebar, akhirnya perceraian tak terhindari.

\section{G.Pembahasan.}

Seperti disebutkan dalam teori cultivasi bahwa siaran televisi mengaburkan esensi dari apa yang ditayangkan mereka hingga menyesatkan pola pikir pemirsa awam dalam memahami makna siaran (pesan) yang sebenarnya, bahkan lebih dari 
itu justru melahirkan pemahaman baru seperti yang diinginkan pengelola (gate keeper) di televisi itu sendiri. Salah satunya adalah pemahaman pemirsa terhadap siaran sinetron televisi adalah mereka mengira apa yang ditayangkan dalam sinetron itu adalah peristiwa nyata yang terjadi di belahan bumi lainnya yang patut dijadikan teladan dalam kehidupan, padahal cerita dalam sinetron tidak labih dari ilusi atau fiksi belaka yang didramatisir oleh penulis naskah menjadi sebuh cerita menarik bagi kalangan pemirsa.

Padahal, disisi lain semua program televisi impor itu, tanpa disadari baik oleh owner televisi maupun para pemirsa di Tanah Air, memiliki kandungan pesanpesan sebagai ujud penjajahan budaya asing bagi budaya dan masyarakat asli Indonesia, sejak zaman dahulu. Misalnya program televisi impor Amerika Latin yang sarat dengan pesan-pesan moral dan ideologi bagi masyarakat Muslim di Tanah Air, tanpa disadari pesan-pesan tersebut memberi tempat terhormat di hati pemirsa Muslim di Tanah Air, yang mestinya pesan-pesan tersebut tak harus masuk ke hati pemirsa Muslim. Teori Imprialisme Culture menyiratkan hal itu dalam memaknai sasaran program televisi nasional kita, padahal ada perbedaan budaya dan tradisi masyarakat antara yang dianut pemirsa dengan tayangan sinetron televisi. Padahal pun, jika sinetron produksi lokal yang diputar jauh lebih efektif untuk membangun dan memperkuat nilai-nilai budaya dan tradisi lokal kita, dibandingkan dengan sinetron impor yang menyesatkan. Hanya saja owner televisi lebih memilih mengimpor program tersebut karena lebih murah dibandingkan memperoduksi sendiri.

Dampak lain dari siaran tersebut dapat dilihat dari semakin meningkatnya angka perceraian yang masuk ke Pengadilan Syari'ah di dua kabupaten di Aceh yaitu Kabupaten Aceh Utara dan Kota Lhokseumawe. Dari paparan data dua tahun terakhir tergambarkan adanya peningkatan angka perceraian yang signifikan.

\section{PENUTUP}

\section{A. Kesimpulan}

Dari uraian diatas dapat disimpulkan sebagai berikut: 1). Siaran televisi yang memiliki pengaruh kuat terhadap keutuhan rumah tangga pasangan usia muda adalah umumnya siaran bertemakan drama rumah tangga seperti sinetron India, 
yang rata-rata menayangkan cerita bersambung yang banyak menarik kalangan masyarakat pedalaman seperti di kawasan pedalaman Aceh Utara. Selain siaran yang bertemakan drama rumah tangga, juga para pemirsa yang cenderung memirsanya dengan penuh perasaan (kekhusyukan), sehingga hampir tidak ada episode yang terlewati tiap kali tayang. Jika ada adegan sedih, para pemirsa ikut menangis, demikian juga jika ada adegan lucu, tidak terlewati tanpa ikut ketawa pemirsa, dan kerap menngidolakan tokoh tertentu dalam sinetron. Rasa fanatis berlebihan terhadap tokoh cerita (yang umumnya para artis ganteng, gagah, dan kaya) menyebabkan pemirsa membandingkan dengan sosok suami mereka yang rata-rata kere, pekerja kasar, kurang gagah dan kampungan. Nah, jika ini yang terjadi, tidak ada para suami di Aceh yang sebandingkan dengan aktor sinetron India seperti Sahrukh Khan, dan lain-lain.

2). Konten siaran televisi yang mempengaruhi kekerasan Isteri terhadap suami, adalah umumnya siaran drama rumah tangga dalam sinetron India rata-rata di bumbui dengan siaran kekerasan, yang ujung-ujungnya kebahagiaan. Para pemirsa ibu-ibu muda di pedalaman juga menyangka kekerasan yang mereka lakukan juga bisa berbuah kebahagiaan, seperti yang mereka tonton di televisi. Kalau kemudian berakhir di balik terali besi penjara (lembaga Pemasyarakatan/LP) adalah sesuatu yang tidak pernah mereka duga.

\section{B. Saran-saran.}

Adapun saran yang dapat diberikan: 1). Karena inti dari semua persoalan yang berakibat munculnya kekerasan terhadap para suami adalah siaran televisi, harus ada perhatian dari pihak berkompeten dengan masalah tersebut. Siaran televisi misalnya adalah tanggung jawab Komisi Penyiaran Indonesia (KPI) dari pusat hingga daerah, setidaknya siaran yang tidak mengandung nilai-nilai edukasi, moralitas sosial, dan nilai budaya lokal apalagi bertentangan dengan nilai-nilai sosial tersebut diawasi kembali oleh KPI. Saran selanjutnya, 2). Pemimpin sosial masyarakat hendaknya juga ikut mengawasi dan memberikan nasehat terutama terkait konten siaran televisi agar tidak sebebas itu memirsa semua siaran, khususnya siaran impor berbeda budaya Islam dengan masyarakat Barat. Pengawasan siaran ini bisa dilakukan dengan menggelar kegiatan literasi media setiap tiga atau empat bulan sekali berkerja sama dengan Komisi Penyiaran 
Indonesia (KPI) lokal di Aceh. Literasi media jangan hanya menyentuh kalangan mahasiswa dan kaum terpelajar, padahal masyarakat awam dan pedalaman justeru lebih penting memahami bagaimana seharusnya mengonsumsi siaran televisi yang benar.

\section{DAFTAR PUSTAKA}

Arikunto, Suharsimi. Penelitian Kualitatif, (Jakarta: Prenada media Group, 2006). Bungin, Burhan. Sosiologi Komunikasi. Jakarta: Prenada media Group, 2006.

Bordieu, Pierre. Arena Produksi Kultural.terj. Bantul: Kreasi Wacana, 2010.

Baran, Stanley dan Davis, Dennis K, Teori Komunikasi Massa. Jakarta: Salemba Humanika, 2010.

Cangara, Hafied. Pengantar Ilmu Komunikasi. Jakarta: Raja Grafindo Persada, 2007.

Rachmat, Jalaluddin. Psikologi Komunikasi. Bandung: Remaja Rosdakarya, 2008.

Fagen, Richard R. Politics and Communications. Boston: Little Brown, 1996.

Fajar, Marhaeni. Ilmu Komunikasi, Teori dan Praktek. Jogyakarta: Graha Ilmu, 2009.

Hikmat, Mahi M. Komunikasi Politik, Teori dan Praktek. Bandung: Simbiosa Rekatama Media, 2011.

Heryanto, Gun Gun. Komunikasi Politik, Sebuah Pengantar. Bogor: Ghalia Indonesia, 2013.

Liliweri, Alo. Komunikasi; Serba Ada Serba Makna.Jakarta: Kencana Prenada Media, 2011.

-------------- Makna Budaya dalam Komunikasi Antar Budaya. Jogyakarta: LkiS, 2003.

Kriyantono, Rachmat. Tehnik Praktis Riset Komunikasi. Jakarta: Kencana Prenada Media Group, 2006.

Kholil, Syukur. Teori Komunikasi Massa. Bandung: Citapustaka Media Perintis, 2011.

Komunikasi Islam. Bandung: Citapustaka Media Perintis, 2007.

Ishak, Aswad, Cs. Mix Methode dalam Penelitian Komunikasi. Jogyakarta: ASPIKOM, Buku Litera dan Perhumas, 2011.

McQuail, Denis. Teori Komunikasi Massa, terj. Jakarta: Erlangga, 1987.

Moeleong, J.Lexi. Metodologi Penelitian Kualitatif. Bandung: Remaja Rosdakarya, 2004. 
Nimmo, Dan. Political Communication and Public Opinion in America, terj. Bandung: Remaja Rosdakarya, 2011

Nimmo, Dan \& Sanders, Keith R. Handbook Political Communication. Beverly Hills: Sage Publication, 1981.

Nurudin. Komunikasi Propaganda. Bandung: Remaja Rosda Karya, 2008.

Nuruddin. Pengantar Komunikasi Massa. Jakarta: Raja Grafindo Perkasa, 2007.

Subiakto, Henry dan Ida, Rachmah. Komunikasi Politik, Media \& Demokrasi. Jakarta: Kencana Prenada Media, 2012.

Weber, Max. Teori Dasar Analisis Kebudayaan. Jogyakarta: IRCiSod, 2012.

Zubaidah, Siti. Kedudukan Wanita dalam Islam. Bandung: Cita Pustaka Media Perintis, 2010 